of outstanding importance is that for the zygote, which exceeds that of the ovum in spite of the inclusion of a large amount of liquid of a lower density.

Within an hour of fertilization taking place the zygote 'puts out' the very familiar fertilization membrane, which is separated from what was the original ovum by a clear space containing a colourless liquid. Measurement has shown that while the diameter of the original ovum is practically unchanged, the diameter of the whole zygote, including the membrane, is considerably increased, with the result that the volume of the zygote is more than twice that of the ovum. In the past, there has been a great diversity of opinion as to the nature both of the fertilization membrane and of the liquid enclosed. From simple basic reasoning we should expect the enclosed liquid to be slightly hypertonic to sea-water and to have a similar density. The density of the Plymouth seawater at $11 \cdot 0^{\circ} \mathrm{C}$. was $1 \cdot 02663$, and the density of the enclosed liquid could therefore scarcely exceed 1.03. Hence, taking the density of the ovum as $1 \cdot 07$ and that of the surrounding liquid as 1.03 , we should expect the density of the whole zygote to be $1 \cdot 05$, or very nearly so, instead of which it is 1.0736 . When, therefore, the ova are left in sea-water, there is a very definite increase in density; and it would seem that this increase can only be attributed to a great intake of calcium ions, which on reaching the cell proper, immediately begin to separate out as cryptocrystalline granules of calcite. Calcium ions would not cause any appreciable increase in density, but calcite granules would, since their density is $2 \cdot 7$.

Much remains to be done, but unfortunately it is too late in the season to undertake it now. We know that spicules of calcite occur in the blastula larva stage. They are definitely crystalline, and in the first stages are intracellular and cannot have come into existence suddenly. This is clearly indicated, apart from anything else, by the gradual increase in density. The recrystallization of calcite from very finely divided granules of calcium carbonate is a well-known but none the less a complicated process even when it takes place in simple inorganic solutions. The protein in the echinoderm cell would probably act as a protective colloid and complicate matters considerably. It is known that calcium ions play a most important part in the early embryology of echinoderms, and also that the presence of excess of lithium ions prevents the normal development of echinoderms, especially in the earliest stages.

This is far too big a problem to discuss here, but the fact remains that while freshly precipitated calcium carbonate recrystallizes normally from seawater, or from a solution of sodium chloride of the same strength, it does not erystallize normally from a solution in which the sodium is replaced by lithium.

The above concept of the great intake of calcium is strongly supported by the work of Ephrussi and Rapkine, as recorded by Needham ${ }^{1}$, on the ash of the echinoderm egg. The figures are as follows :

$\begin{array}{llllc}\text { Hours after fertilization } & & 0 & 12 & 40 \text { (Pluteus) } \\ \text { Total ash, \% dry weight } & \ldots & 1 \cdot 5 & 9 \cdot 1 & 16.8 \\ \text { Total ash, \% wet weight } & \ldots & 0.34 & 2.06 & 3.56\end{array}$

There are, of course, slight variations in the densities and also in the volumes of ova and zygotes, but in all cases investigated so far the density of the latter exceeds that of the former, which is the really important point.
In a previous communication ${ }^{2}$, I recorded the fact that a ripe ovum in the oviduct of Calanus finmarchicus may increase its volume nearly twentytwo times within a few hours of extrusion. I also pointed out that in certain cases such volume changes took place irrespective of syngamy. Clearly in all these cases a consideration of density must preclude the assumption that these great changes in volume can be due to an intake of water alone.

The Aquarium,

A. G. Lowndes.

Plymouth.

1 "Chemical Embryology" (Camb. Univ. Press), 1271.

${ }^{2}$ Lowndes, A. G., Proc. Zoo. Soc. London, A, 113, 28 (1943).

\section{Composition of Coal}

DetarLed research into the composition of coal demonstrates its intricacy. There can be no true understanding of this complicated and important substance if the results of research are confused by the use in varying senses of descriptive terms.

A recrudescence of confusion has recently arisen around the use of the word 'anthraxylon' as though it were synonymous with 'vitrain'. In their book "Geology in the Service of Man", Prof. W. G. Fearnsides and Dr. O. M. B. Bulman say (p. 108) "black, shining, bright coal ('vitrain' or 'anthraxylon') also composed of woody fragments". This is misleading : 'vitrain' and 'anthraxylon' are not equivalent, and 'vitrain' may or may not be composed of woody fragments.

I originally demonstrated and defined 'vitrain' in $1919^{1}$; in the following year Dr. Thiessen ${ }^{2}$ described 'anthraxylon' as being layers which "correspond to the larger pieces of woody peat". Following my paper of $1935^{3}$, an international agreement about coal terminology was achieved at the congress at Heerlen in the autumn of the same year ${ }^{4}$.

It is particularly unfortunate at the present time when coal research is receiving wider recognition that confusion should be exacerbated, so that one must state emphatically that the term 'anthraxylon' cannot be used as the equivalent of 'vitrain'.

Marte C. Stopes.

Palæobotanical Laboratory, Norbury Park, Dorking.

1 Stopes, M. C., Proc. Roy. Soc., B, 90, 469 (1919).

2 Thiessen, R., Bull. 117, U.S. Bureau Mines, Washington (1920).

- Stopes, M. O., Fuel, 14 (1935).

- Jongmans, W. J., Agreed details of "Nomenclature of Coal Petrography", Compt. Rend. Congres Heerlen, Sept. 1935 (Maestricht, 1938).

\section{Factors in the Production of Honey}

I MusT apologize for having misquoted Miss Betts in my article in Nature of May 13. Her optimum figure for maximum sugar intake is 56 per cent, not 40 , and incidentally is nearly independent of temperature. My conclusion is not affected. It is interesting to note that for a given concentration she established that the sugar intake is roughly doubled between $15^{\circ} \mathrm{C}$. and $25^{\circ} \mathrm{C}$. and follows roughly a linear law over a wider temperature range. The optimum concentration is nearly independent of temperature.

E. B. WedMore. 